U.S. Department of the Interior

U.S. Geological Survey

Sampling of Volatile Organic Compounds in Ground Water by Diffusion Samplers and a Low-Flow Method, and Collection of BoreholeFlowmeter Data, Hanscom Air Force Base, Massachusetts

BY PETER E. CHURCH and FOREST P. LYFORD

Open-File Report 00-207

Prepared in cooperation with the

AIR FORCE CENTER FOR ENVIRONMENTAL EXCELLENCE and the U.S. ENVIRONMENTAL PROTECTION AGENCY

Northborough, Massachusetts 2000 


\section{U.S. DEPARTMENT OF THE INTERIOR \\ BRUCE BABBITT, Secretary}

\section{U.S. GEOLOGICAL SURVEY}

Charles G. Groat, Director

The use of trade or product names in this report is for identification purposes only and does not constitute endorsement by the U.S. Geological Survey.

For additional information write to:

Chief, Massachusetts-Rhode Island District

U.S. Geological Survey

Water Resources Division

10 Bearfoot Road

Northborough, MA 01532
Copies of this report can be purchased from:

U.S. Geological Survey

Branch of Information Services

Box 25286

Denver, CO 80225-0286 


\section{CONTENTS}

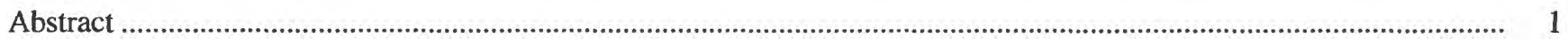

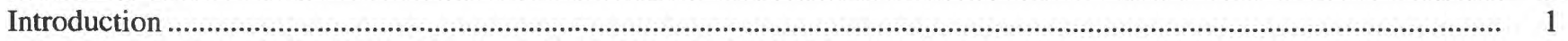

Description of the Study Area at the Hanscom Air Force Base ...............................................................

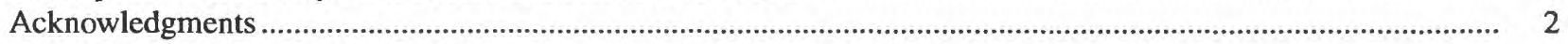

Methods used for Volatile Organic Compound Sampling and Measuring Vertical Flow in Wells.................................... 4

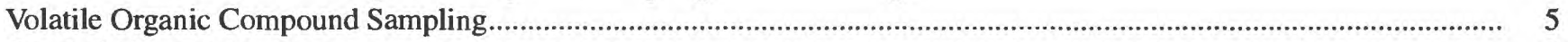

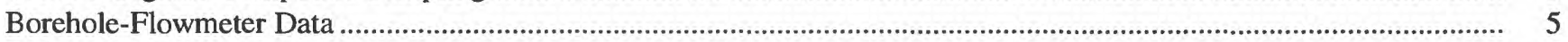

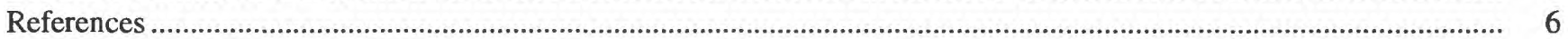

FIGURES

1. Map showing location of study area, altitude of water table in May 1998, location of wells sampled with water diffusion samplers and a low-flow method, wells logged with a borehole flowmeter, and restoration wells, Hanscom Air Force Base, Bedford, Massachusetts.

\section{TABLES}

1. Construction data for wells sampled with water diffusion samplers and a low-flow sampling method, installation and retrieval dates of water diffusion samplers, water levels, and low-flow sampling collection dates, Hanscom Air Force Base, Bedford, Mass., April-May, 1999.

2. Compounds analyzed in water from diffusion and low-flow samples and their minimum reporting limits

3. Concentrations of volatile organic compounds in ground-water samples collected with water diffusion samplers from wells at Hanscom Air Force Base, May 10-13, 1999

4. Concentrations of volatile organic compounds in ground-water samples collected with a low-flow sampling method from wells at Hanscom Air Force Base, May 10-14, 1999

5. Concentrations of volatile organic compounds in duplicate ground-water samples collected with water diffusion samplers and a low-flow sampling method from wells at Hanscom Air Force Base, May 10-14, 1999

6. Concentrations of volatile organic compounds in trip and equipment blank samples, Hanscom Air Force Base, May 10-14, 1999

7. Vertical flow in four screened wells and one open borehole, Hanscom Air Force Base, June 1-4, 1999 
CONVERSION FACTORS, VERTICAL DATUM, AND WATER-QUALITY

INFORMATION

CONVERSION FACTORS

\begin{tabular}{rll}
\hline Multiply & By & To obtain \\
\hline feet (ft) & 0.3048 & meters \\
gallon (gal) & 3.785 & liter \\
gallons per minute (gal/min) & 3.785 & liters per minute \\
inches (in.) & 2.54 & centimeters \\
mil & 0.0254 & millimeters \\
miles (mi) & 1.609 & kilometers \\
square miles ( $\left.\mathrm{mi}^{2}\right)$ & 12.590 & square kilometers \\
& & \\
Temperature in degrees Celsius $\left({ }^{\circ} \mathrm{C}\right) \mathrm{can}$ be converted to degrees Fahrenheit $\left({ }^{\circ} \mathrm{F}\right)$ as follows: \\
\end{tabular}

VERTICAL DATUM

Sea Level: In this report, "sea level" refers to the National Geodetic Vertical Datum of 1929 (NGVD of 1929) - a geodetic datum derived from a general adjustment of the first-order level nets of the United States and Canada, formerly called Sea Level Datum of 1929.

\section{WATER-QUALITY INFORMATION}

Specific conductance is given in microsiemens per centimeter at 25 degrees Celsius $\left(\mu \mathrm{S} / \mathrm{cm}\right.$ at $\left.25^{\circ} \mathrm{C}\right)$.

Concentration of chemical constituents in water are given in micrograms per liter $(\mu \mathrm{g} / \mathrm{L})$.

Turbidity is given in nephelometric units. 


\title{
Sampling of Volatile Organic Compounds in Ground Water by Diffusion Samplers and a Low-Flow Method, and Collection of Borehole- Flowmeter Data, Hanscom Air Force Base, Massachusetts
}

\author{
By Peter E. Church and Forest P. Lyford
}

\begin{abstract}
Ground-water samples were collected for analysis of volatile organic compounds in May 1999 at the Hanscom Air Force Base, Bedford, Massachusetts with water diffusion samplers and a conventional low-flow sampling method to evaluate the use of diffusion samplers as a quick and inexpensive alternative method for groundwater monitoring at the site. Additional water samples were collected by the water diffusion sampler method from long-screen wells to examine vertical distributions of volatile organic compounds. Vertical flow was also measured in selected long-screen wells and in an open borehole in fractured bedrock, where water samples from water diffusion samplers indicated vertical differences in concentrations of volatile organic compounds, to identify zones of water gains and losses under static conditions and pumping conditions.
\end{abstract}

\section{INTRODUCTION}

Volatile organic compounds (VOCs), which include chlorinated solvents, petroleum hydrocarbons, and their biodegradation products, are present in ground water at Hanscom Air Force Base (AFB), Massachusetts. Remediation efforts to remove VOCs from ground water have been ongoing since 1991. Thousands of dollars are spent each year at this facility to collect water samples from monitoring wells using conventional low-flow techniques as part of a remediation-monitoring program; however, the Air Force is seeking lower-cost and faster sampling methods that will still yield reliable results.

Vroblesky and Hyde (1997) describe an inexpensive and effective sampling method that uses water-to-water diffusion samplers (referred to as diffusion samplers in this report) placed in wells. Although this passive method has yielded promising results in some settings (Vroblesky and Hyde, 1997), testing is needed to evaluate its suitability for long-term monitoring in wells at Hanscom AFB. Also of concern at this site is the effectiveness of diffusion samplers for detecting the potential vertical redistribution of VOCs in long-screen wells and in an open borehole in fractured bedrock.

The U.S. Geological Survey (USGS), in cooperation with the Air Force Center for Environmental Excellence (AFCEE), Brooks AFB, San Antonio, Texas, and in consultation with the Restoration Program Manager at Hanscom AFB, designed a ground-water-sampling and boreholelogging program to compare VOC concentrations in water samples collected with diffusion samplers and a low-flow sampling method. To support interpretation of the water-quality data, multiple diffusion samplers were placed in long-screen wells and an open borehole in bedrock to examine the vertical distribution of VOC concentrations and to evaluate possible effects of flow in well screens on the vertical distribution of VOCs in selected wells.

The USGS collected ground-water samples with diffusion samplers installed in wells during April 1999; samplers were retrieved in May 1999. The IT Corporation, Hopkinton, Mass., under contract to the Hanscom AFB, collected ground-water samples with a 
low-flow sampling method in May 1999. Vertical-flow measurements were conducted by the USGS in four long-screen wells and in an open borehole in fractured bedrock on June 1999.

The purpose of this report is to present the results from the sampling of VOCs in ground water by diffusion samplers and a low-flow method at the Hanscom AFB in Massachusetts. The report also presents the data from the borehole-flowmeter tests. It is beyond the scope of this report to interpret the relation of VOC data collected by the two methods, the vertical distribution of VOCs in long-screen wells, and the results of vertical-flow measurements in longscreen wells.

\section{Description of Study Area at the Hanscom Air Force Base}

The study area is in the northeastern part of the Hanscom AFB in Bedford, Mass. (fig. 1). Physical, hydrogeological, and hydraulic characteristics of this area have been described by Haley \& Aldrich, Inc. $(1996,1998)$. The land surface ranges in altitude from about 115 to $125 \mathrm{ft}$ in most of the study area. In the west central part of the study area, near well A-3, land surface altitude increases to greater than $145 \mathrm{ft}$.

Swamps occupy the north central and eastern part of the study area. Surface drainage at the Hanscom AFB is controlled by storm culverts and swales that drain to the northwest, northeast, and east.

VOCs are present in an unconfined surficial aquifer, a deep confined aquifer, and the underlying fractured bedrock aquifer. The surficial aquifer consists of fine sand and silt of glacial outwash deposits. The deep confined aquifer consists of a wide range of particle sizes from silt to boulders [previously described as glacial till by Haley \& Aldrich, Inc. (1996), and hereafter referred to as till] below a confining layer of lacustrine silt. The bedrock is composed primarily of granitic gneiss and schists. The bedrock surface slopes from a depth of about 20 to 30 $\mathrm{ft}$ below land surface in the northern part of the study area to a depth of about 100 to $120 \mathrm{ft}$ below land surface in the southern part of the study area. The outwash deposits at the surface range in thickness from about 8 to $28 \mathrm{ft}$ and grade from silty, fine to medium sand in the upper part to silty, fine to coarse sand in the lower part. The lacustrine deposit ranges in thickness from less than $1 \mathrm{ft}$ to about $48 \mathrm{ft}$ and grades from fine sand and silt in the upper part to clayey silt in its lower part. Lacustrine sediments are not present in the west central part of the study near well A-3 where the outwash is directly underlain by the sandy and gravelly till, which ranges in thickness from about 8 to $60 \mathrm{ft}$. In this report, the outwash deposits will be referred to as the surficial aquifer, the confined till deposit as the till aquifer, and the fractured bedrock as the bedrock aquifer.

Water-level measurements in May 1998 (Haley \& Aldrich, Inc., 1998) indicate that the water table within the study area ranged in altitude from about 116 to $140 \mathrm{ft}$ (fig. 1). The water table is primarily in the surficial aquifer at depths from 0 to about $12 \mathrm{ft}$. Ground-water flow in the surficial aquifer is generally from the southwest to the northeast. In the west central and southeastern parts of the site, however, water-table depths and directions of flow are affected by the continuous pumping from restoration wells in the till and bedrock aquifers (fig. 1). Pumping from Restoration Wells No. 1, No. 2, No. 3, and No. 4 (fig. 1) have formed a depression in potentiometric heads in the till and bedrock aquifers from the southeastern to the northwestern parts of the site. Aquifer-test data from selected wells indicate hydraulic conductivities range from about 5 to $65 \mathrm{ft}$ per day in the till aquifer and from about 0.1 to $0.6 \mathrm{ft}$ per day in the bedrock aquifer (Haley \& Aldrich, Inc., 1996).

\section{Acknowledgments}

The author thanks personnel of the Air Force Center for Environmental Excellence (AFCEE), Brooks Air Force Base, San Antonio, Texas, and Thomas Best, Restoration Program Manager, Hanscom AFB, for their cooperation in developing the study program. Thomas Best provided pertinent site information and assistance in the field, and personnel of IT Corporation, Hopkinton, Mass., collected the low-flow samples. The helpful comments throughout this study from Richard Willey, Office of Site Remediation and Restoration, U.S. Environmental Protection Agency, Region I, Boston, Mass., are greatly appreciated. William J. Andrade, Analytical Specialist and Joseph Montanaro, Analyst, U.S. Environmental Protection Agency, Region I, Lexington, Mass., are also acknowledged for analyzing both the diffusion and low-flow samples and for providing guidance on quality-assurance procedures during the collection of water samples. 


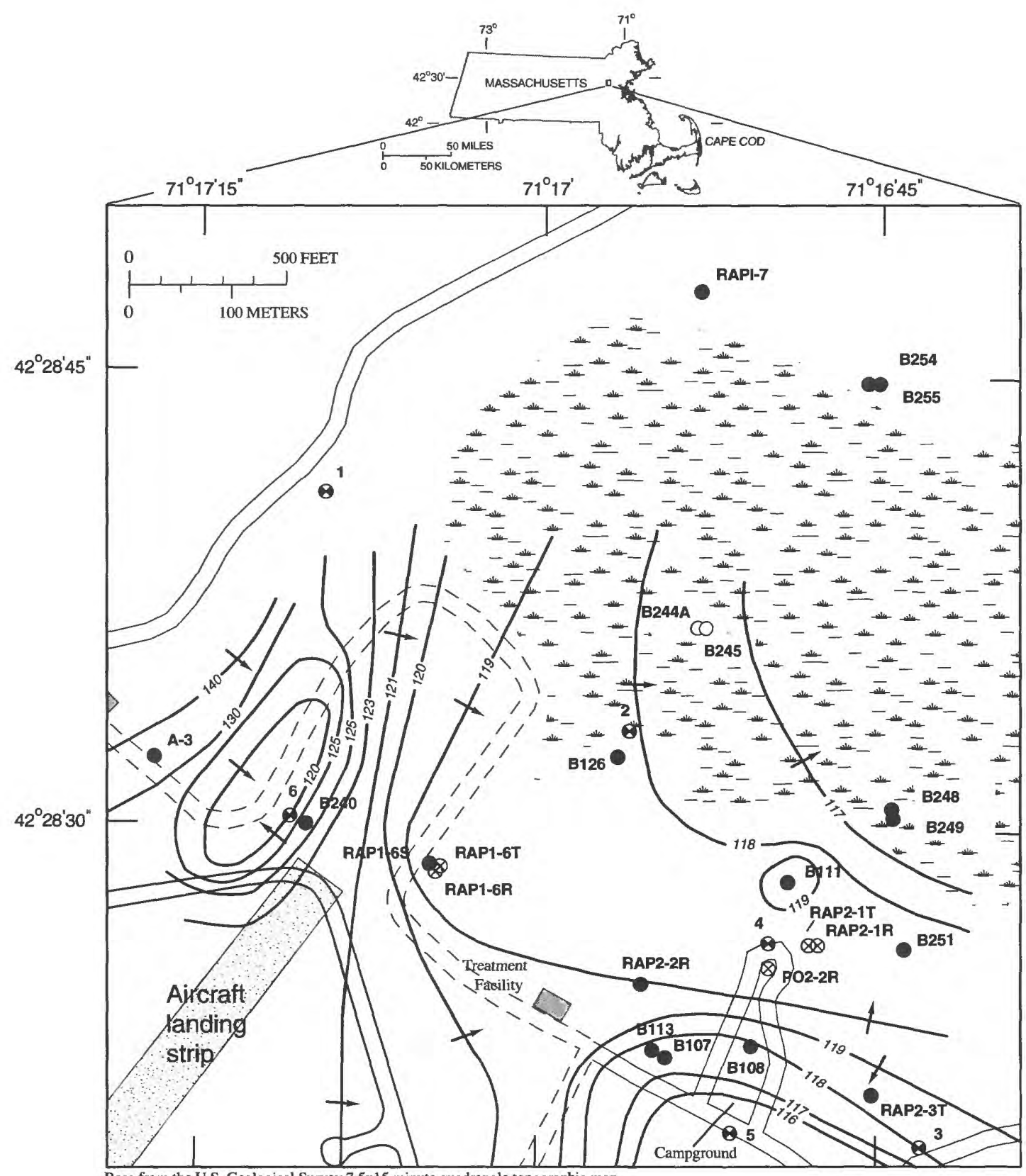

Base from the U.S. Geological Survey $7.5 \times 15$ minute quadrangle topographic map Maynard, Massachusetts base map, 1:25,000, 1987 Based on Massachusetts coordinate system

\section{EXPLANATION}

\begin{tabular}{|c|c|}
\hline S & SWAMP \\
\hline$-117-$ & $\begin{array}{l}\text { WATER-TABLE CONTOURS-SH } \\
\text { altitude of water table in May } 1998 \\
\text { and Aldrich, Inc., 1998). } \\
\text { Contour interval is variable. Datum } \\
\text { sea level. }\end{array}$ \\
\hline $\mathrm{O}^{\mathrm{B245}}$ & $\begin{array}{l}\text { WELLS SAMPLED BY WATER } \\
\text { DIFFUSION METHOD AND } \\
\text { IDENTIFIER }\end{array}$ \\
\hline 8249 & $\begin{array}{l}\text { WELLS SAMPLED BY WATER } \\
\text { DIFFUSION AND LOW-FLOW } \\
\text { METHOD AND IDENTIFIER }\end{array}$ \\
\hline
\end{tabular}

Figure 1. Location of study area, altitude of water table in May 1998, location of wells sampled with water diffusion samplers and a low-flow method, wells logged with a borehole flowmeter, and restoration wells, Hanscom Air Force Base, Bedford, Massachusetts. 


\section{METHODS USED FOR VOLATILE ORGANIC COMPOUND SAMPLING AND MEASURING VERTICAL FLOW IN WELLS}

The diffusion samplers were constructed using the method described by Vroblesky and Hyde (1997). Polyethylene sleeves, 2-inch wide by 18-inch long, and 4 mil thick, were heat sealed at one end, filled with about $300 \mathrm{~mL}$ of deionized water, and then closed by heat seal at the other end, after the elimination of any air space. The water-filled polyethylene tubes were slid into 24-inch long, 1.5-inch diameter polyethylenemesh tubing and secured to cords at both ends with plastic cable ties.

The diffusion samplers were then lowered into wells, either to the well screens or the open borehole in bedrock, with weights attached to the end of the cords to ensure that the samplers were placed, and remained, at the selected depths in the wells. The diffusion samplers were retrieved about three weeks later to allow time for VOCs diffusing into the samplers to equilibrate with VOCs in the aquifer.

Upon retrieval, the polyethylene mesh was partially cut open and a small slit was made at the top of the samplers and the water samples were decanted into 40-mL glass vials and capped. Hydrochloric acid (about $0.1 \mathrm{~mL}$ ) was added to the vials before the sample was added to preserve the samples. Once capped, the vials were packed in ice. Samples were hand delivered to the nearby U.S. Environmental Protection Agency (USEPA) laboratory in Lexington, Mass., at the end of each day for analysis of VOCs by USEPA method 8260 (U.S. Environmental Protection Agency, 1996). Quality assurance for diffusion samples included an equipment blank, daily trip blanks, and duplicate samples. The USEPA laboratory qualityassurance procedures included matrix spike samples made from selected diffusion samples and lab blanks.

The low-flow method is designed for collection of water samples adjacent to well screens with minimal disturbance to the aquifer and minimal drawdown in the well. This method eliminates the need for evacuation of water from within the well casing above the screen. To ensure that water samples are obtained from the screened sections of wells, and not from the well storage, pumping rates are adjusted so that drawdowns in wells are minimal.

In this study, a bladder pump was used to collect water samples by the low-flow sampling method. The pump intake was placed at the mid-point of each well screen, or in the case of water-table wells, the pump intake was placed at the mid-point between the water level and the bottom of the screen. Purge rates were adjusted from about 0.1 to 1.0 liters per minute according to the rate of drawdown in each well. Water temperature, specific conductance, $\mathrm{pH}$, and turbidity were monitored at 5-minute intervals, and a sample was collected after these water-quality parameters stabilized. The stabilization criteria for these waterquality parameters are: water temperature, \pm 1 degree Celsius; specific conductance, \pm 5 percent, $\mathrm{pH}, \pm 0.1 \mathrm{pH}$ units; and turbibity, \pm 10 nephelometric units. Samples were processed and analyzed using the same procedures that were used with the diffusion samples.

Vertical flow in wells was measured using a heat-pulse flowmeter. This meter consists of a downhole probe with heat sensors equidistant above and below a heat source at the bottom of the probe (Keyes, 1990). The heat source is a thin metal mesh through which water flows. A pulse of electricity causes this mesh to increase in temperature, thereby increasing the temperature of a small quantity of water. Travel time of the heated water is measured as it passes by either of the heat sensors, and vertical direction is determined by which of sensors detected the heated water. The annular space between the probe's heat source and the well screen or casing must be sealed to direct vertical flow, if any, through the metal mesh. Travel times are calibrated to well diameter, and flow rates measured are expressed in gallons per minute ( $\mathrm{gal} / \mathrm{min})$. Borehole-flowmeter logging in long-screen wells and in an open borehole in fractured bedrock were conducted to identify zones of water gains and losses and directions of vertical flow in the borehole under static and pumping conditions. If the annular space between the heat source and the well screen has been properly sealed and the waterlevel changes caused by introducing the probe have stabilized, accuracies of \pm 5 percent can be obtained for vertical-flow measurements under static conditions. The minimum flow rate that can be detected by the borehole flowmeter used at this site is reported as 0.03 $\mathrm{gal} / \mathrm{min}$ by the manufacturer (Mount Sopris Intruments, 
Golden, Colo.). Field experience with this heatpulse flowmeter indicate that flow rates as low as $0.01 \mathrm{gal} / \mathrm{min}$ can be detected before the measurement is affected by thermal convection (Bruce P. Hansen, USGS, oral commun., 1999).

\section{VOLATILE ORGANIC COMPOUND SAMPLING}

Seventy diffusion samplers were placed in 23 wells on April 21 and 22, 1999, for measurement of VOC concentrations in ground water. Multiplediffusion samplers were typically placed in wells with screen lengths 10 - $\mathrm{ft}$ long or greater ( 14 of the 23 wells) and were also placed in an open bedrock well. Diffusion samplers were retrieved between May 10 and 13,1999 , generally in order of increasing VOC concentration as determined from results of previous sampling (Haley \& Aldrich, Inc., 1998). Diffusion samplers are identified by the name of the well in which they were installed. In wells where multiplediffusion samples were installed, the letters A, B, C, D, or $\mathrm{E}$, in order of increasing depth, were added to sampler name. A list of the wells sampled and relevant sampling information are summarized in table 1 (at the back of report). A list of compounds analyzed in water from diffusion and low-flow samples, and their minimum reporting levels, is provided in table 2 (at the back of report). Concentrations of VOCs detected in diffusion samples are listed in table 3 (at the back of report).

The single diffusion sampler installed in well screens less than $10 \mathrm{ft}$ in length and the mid-point diffusion sampler of the multiple samplers installed in the long screen wells were placed at the mid-point of the screens for comparison with VOC concentrations in samples collected by the low-flow method. At longscreen water-table well RAP1-6S, however, only two diffusion samples were installed because there was only about $6 \mathrm{ft}$ of water in the 14.5 -foot screen. VOC concentrations from these two samplers were averaged for comparison with the concentrations in the sample collected by the low-flow method.

Samples were collected from 21 wells by a lowflow sampling method with a bladder pump between May 10 and 14, 1999, after the diffusion samplers were retrieved. Two of the 23 wells sampled by the waterdiffusion method, wells B244A and B245, were not sampled by the low-flow method because access to these wells, which are located in the swamp in the northeastern part of the study area (fig. 1), was difficult. Low-flow water samples were generally collected in the same order that the diffusion samplers were retrieved from the wells (table 1). Water samples from five wells were collected on the same day, samples from 15 wells were collected on the next day, and a sample from one well was collected two days after the diffusion samplers were retrieved (table 1).

Concentrations of VOCs detected in the low-flow samples method are listed in table 4 (at the back of report). VOC concentrations of duplicate samples from both diffusion and the low-flow method are recorded in table 5 (at the back of report). Diffusion and low-flow blank sample analysis results are recorded in table 6 (at the back of report).

The principal VOCs detected by both sampling methods were 1,2-dichloroethylene isomers and trichloroethylene. Concentrations of these VOCs in well water sampled by the diffusion-sampler method range from not detected above $5 \mu \mathrm{g} / \mathrm{L}$ (minimum reporting levels of 5 micrograms per liter) to 6,800 $\mu \mathrm{g} / \mathrm{L}$ and $4,900 \mu \mathrm{g} / \mathrm{L}$, respectively, and by the low-flow method, from not detected to $6,400 \mu \mathrm{g} / \mathrm{L}$ and 4,900 $\mu \mathrm{g} / \mathrm{L}$, respectively. Other volatile organic compounds commonly detected, but at much lower concentrations, include acetone, vinyl chloride, 1,1-dichloroethylene, and 1,1-dichloroethane. The presence of acetone is primarily the result of lab analyses (William $\mathbf{J}$.

Andrade, Analytical Specialist, U.S. Environmental Protection Agency, oral commun., 1999).

\section{BOREHOLE-FLOWMETER DATA}

Borehole-flowmeter data from four long-screen wells (screens greater than $15 \mathrm{ft}$ long) and one open borehole in bedrock are shown in table 7 (at the back of report). The small downward flow measured in well casings under static conditions in wells $\mathrm{PO} 2-2 \mathrm{R}$, RAP2-1R, and RAP1-6R are the result of the water level not being fully stabilized after the introduction of the heat-pulse flowmeter. Differences of \pm 10 percent between flow measurements within well casings under pumping conditions and the measured flow pumped from the well can be attributed to small errors in either measurement (table 7).

Flowmeter results from the open borehole in bedrock well RAP2-1R underestimate vertical flow because the annular space between the heat source and 
the bedrock wall could not be adequately sealed. Vertical flow that may exist under static conditions could pass outside of the probe and thus, not be detected. Upward flow under pumping conditions is significantly underestimated because considerably more water was likely to have flowed through the annular space between borehole wall and the heat source than through the heat source. Additionally, the substantially different flow rates measured in the bottom of the well casing under pumping conditions $(0.045 \mathrm{gal} / \mathrm{min})$ and the expected flow rate due to pumping ( $0.6 \mathrm{gal} / \mathrm{min}$ ) (table 7 ) suggests that the annular space between the well casing and the probe's heat source was poorly sealed, that depth of the bottom of the well casing is slightly higher in altitude than reported, or both. Although the bulk of the probe was likely within the well casing, the heat source, which is located at the bottom of the probe, may have been in the open borehole.

\section{REFERENCES}

Haley \& Aldrich, Inc., 1996, Architect-engineer field investigation report, sampling round no. 9, June-July 1996, Long-term sampling program, Hanscom Air Force Base, Bedford, Massachusetts, vols. 1 and 2: Cambridge, Mass., Haley \& Aldrich, Inc., variously paged.

1998, Architect-engineer field investigation report, sampling round no. 11, May 1998, Long-term sampling program, Hanscom Air Force Base, Bedford, Massachusetts: Boston, Mass., Haley \& Aldrich, Inc., variously paged.

Keyes, W.S., 1990, Borehole geophysics applied to groundwater investigations: U.S. Geological Survey Techniques of Water-Resources Investigations, book 2, chap. E2,150 p.

U.S. Environmental Protection Agency, 1996, Test method for evaluating solid waste, physical/chemical methods, SW-846: 3d ed., Revision 2, v. IB, chap. 4, Section 4.3.2, Final update III, December 1996, p. 1-86.

Vroblesky, D.A. and Hyde, W.T., 1997, Diffusion samplers as an inexpensive approach to monitoring VOCs in ground water: Ground Water Monitoring and Remediation, v. 17, no. 3, p. 177-184. 
TABLES 


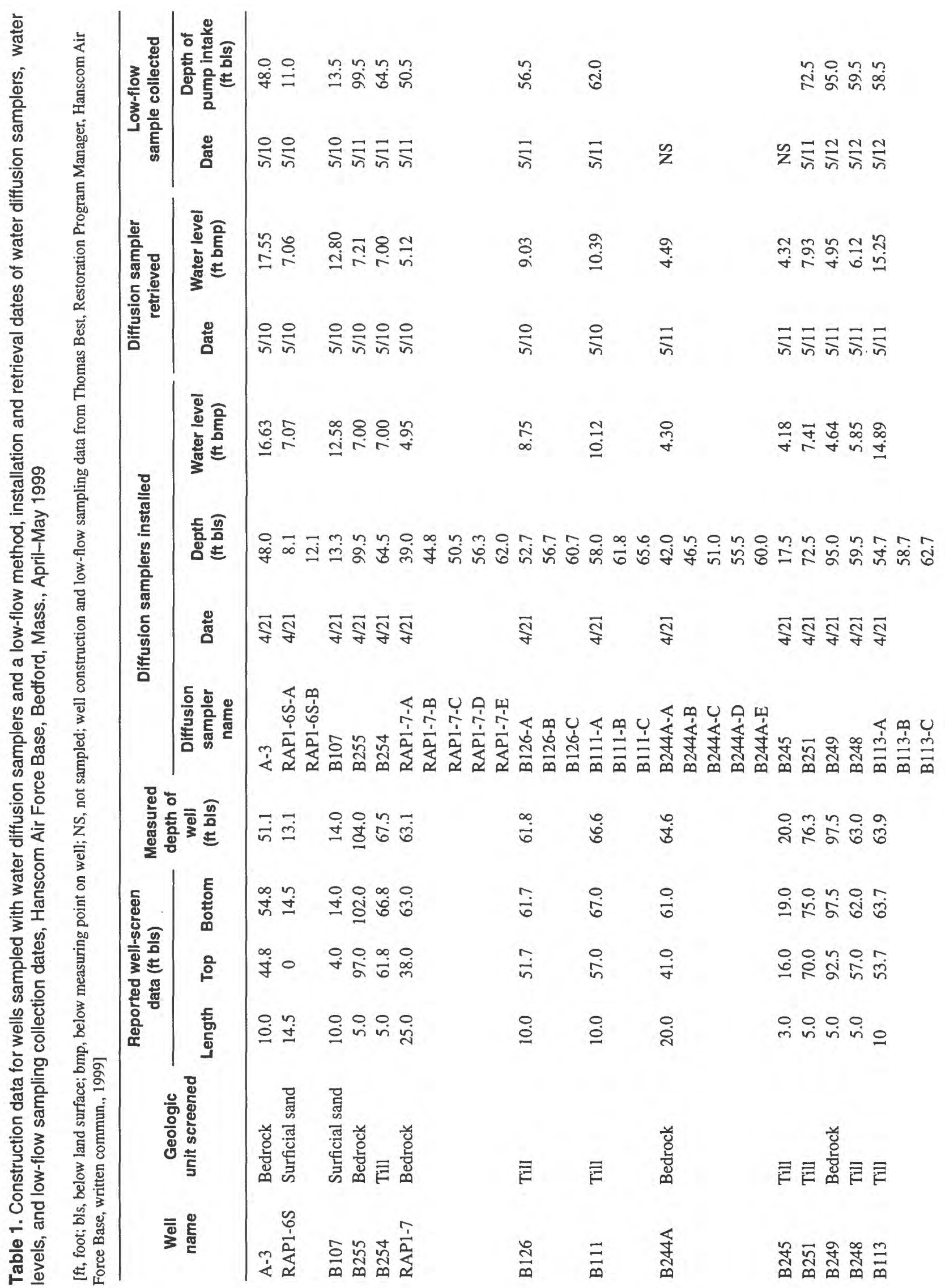




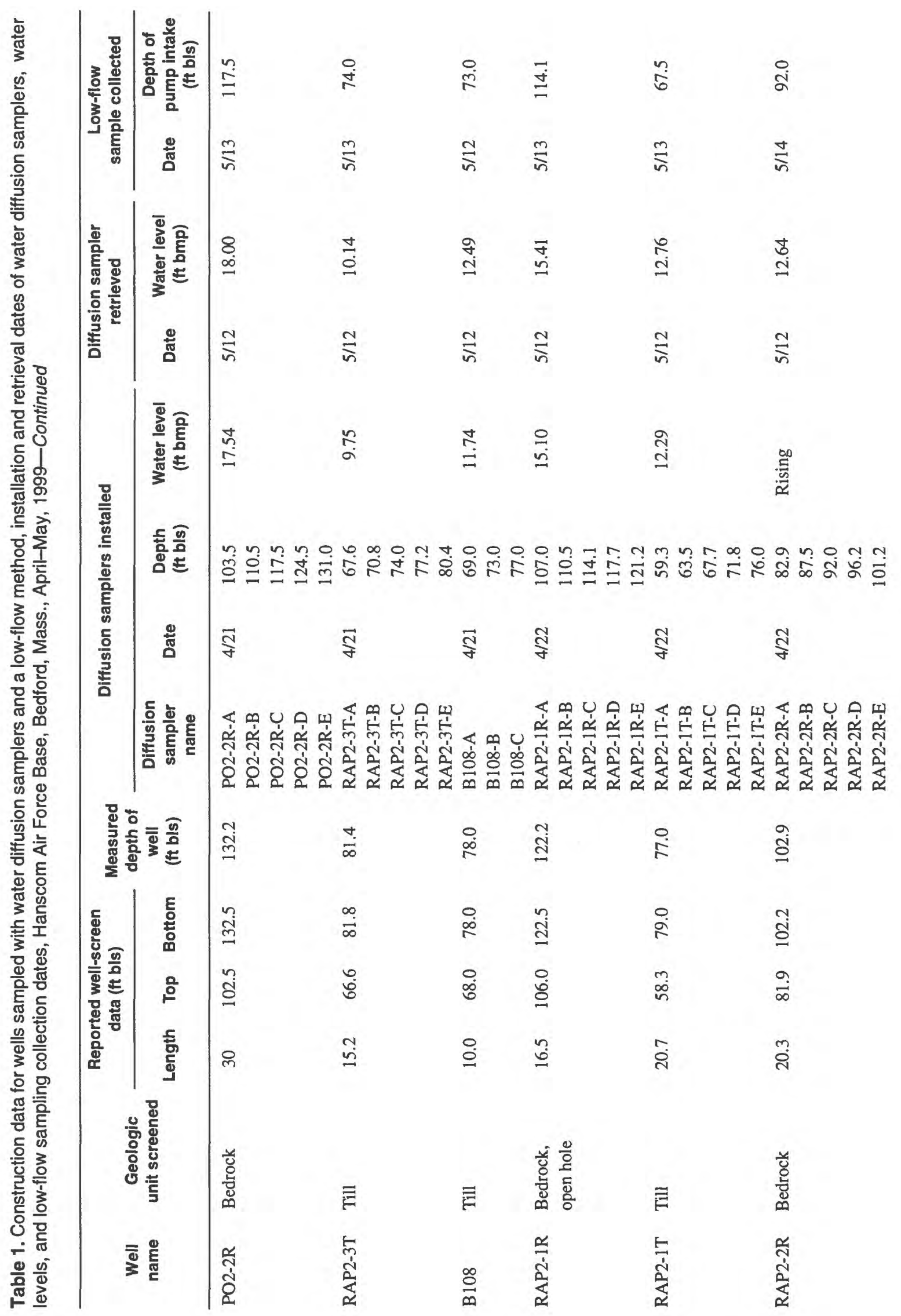




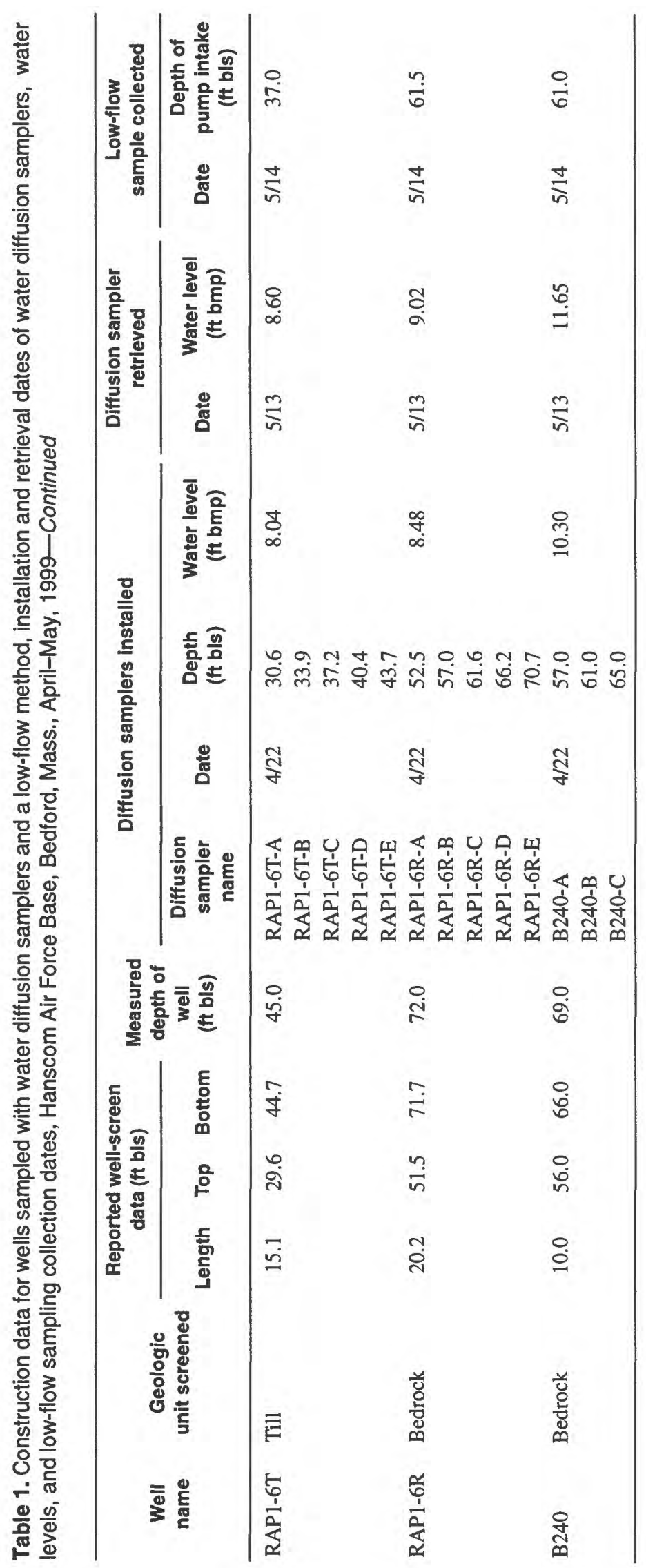


Table 2. Compounds analyzed in water from diffusion and low-flow samples and their minimum reporting limits

\begin{tabular}{|c|c|}
\hline Compound & $\begin{array}{l}\text { Minimum reporting } \\
\text { limit ( } \mu g / L)\end{array}$ \\
\hline Acetone & 10 \\
\hline Acrolein & 50 \\
\hline Acrylonitrile & 25 \\
\hline Benzene & 5 \\
\hline Bromodichloromethane & 5 \\
\hline Bromoform & 5 \\
\hline Bromomethane & 5 \\
\hline 2-Butanone (MEK) & 20 \\
\hline Carbon Disulfide & 15 \\
\hline Carbon Tetrachloride & 5 \\
\hline Chlorobenzene & 5 \\
\hline Chloroethane & 5 \\
\hline 2-Chloroethylvinyl ether & 15 \\
\hline Chloroform & 5 \\
\hline Chloromethane & 5 \\
\hline Dibromochloromethane & 5 \\
\hline 1,2-Dibromoethane (EDB) & 5 \\
\hline Dichlorobenzene isomers & 5 \\
\hline 1,1-Dichoroethane & 5 \\
\hline 1,2-Dichloroethane & 5 \\
\hline 1,1-Dichloroethylene & 5 \\
\hline 1,2-Dichloroethylene isomers & 5 \\
\hline 1,2-Dichloropropane & 5 \\
\hline c-1,3-Dichloropropene and/or1,1- & \\
\hline Dichloropropene & 5 \\
\hline t-1,3-Dichloropropene & 5 \\
\hline Ethylbenzene & 5 \\
\hline Ethyl ether & 15 \\
\hline 2-Hexanone & 3 \\
\hline Methylene Chloride & 5 \\
\hline 4-Methyl-2-Pentanone (MIBK) & 3 \\
\hline Naphthalene & 5 \\
\hline Styrene & 5 \\
\hline 1,1,1,2-Tetrachloroethane & 5 \\
\hline 1,1,2,2-Tetrachloroethane & 5 \\
\hline Tetrachloroethylene & 5 \\
\hline Tetrahydrofuran & 35 \\
\hline Toluene & 5 \\
\hline 1,1,1-Trichloroethane & 5 \\
\hline 1,1,2-Trichloroethane & 5 \\
\hline Trichloroethylene & 5 \\
\hline Trichlorofluoromethane & 5 \\
\hline 1,1,2-Trichloro-1,2,2-Trifluoroethane & 5 \\
\hline Vinyl Acetate & 15 \\
\hline Vinyl Chloride & 5 \\
\hline Xylenes (total) & 5 \\
\hline
\end{tabular}


Table 3. Concentrations of volatile organic compounds in ground-water samples collected with water diffusion samplers from wells at Hanscom Air Force Base, Bedford, Mass., May 10-13, 1999

[B, analyte found in lab blank; E, estimated value exceeds calibration range; L, estimated value is below calibration range; --(5), not detected at reporting limit of 5 micrograms per liter]

\begin{tabular}{|c|c|c|c|c|c|c|c|c|c|c|c|}
\hline \multirow[b]{2}{*}{$\begin{array}{c}\text { Well } \\
\text { name }\end{array}$} & \multirow[b]{2}{*}{$\begin{array}{l}\text { Water } \\
\text { diffusion } \\
\text { sampler } \\
\text { name }\end{array}$} & \multicolumn{10}{|c|}{ Volatile organic compounds in micrograms per liter } \\
\hline & & Acetone & Benzene & 2-Butanone & $\begin{array}{l}\text { Chloro- } \\
\text { methane }\end{array}$ & $\begin{array}{c}\text { 1,1- } \\
\text { Dichloro- } \\
\text { ethane }\end{array}$ & $\begin{array}{c}\text { 1,1- } \\
\text { Dichloro- } \\
\text { ethylene }\end{array}$ & $\begin{array}{l}\text { 1,2- } \\
\text { Dichloro- } \\
\text { ethylene } \\
\text { isomers }\end{array}$ & Toluene & $\begin{array}{l}\text { Trichloro } \\
\text { ethylene }\end{array}$ & $\begin{array}{c}\text { Vinyl } \\
\text { chloride }\end{array}$ \\
\hline A-3 & A-3 & $--(10)$ & $--(5)$ & $--(20)$ & $--(5)$ & $--(5)$ & $--(5)$ & $--(5)$ & $-(5)$ & $--(5)$ & $--(5)$ \\
\hline RAP1-6S & RAP1-6S-A & $11(\mathrm{~B})$ & $--(5)$ & $--(20)$ & $2.6(\mathrm{~L})$ & $--(5)$ & $--(5)$ & 37 & $--(5)$ & 9.2 & $--(5)$ \\
\hline RAP1-6S & RAP1-6S-B & $6(\mathrm{~B})$ & $--(5)$ & $--(20)$ & $--(5)$ & $--(5)$ & $--(5)$ & 59 & $--(5)$ & 16 & $3.9(\mathrm{~L})$ \\
\hline B107 & B107 & 8.1(B) & $--(5)$ & $--(20)$ & $--(5)$ & $--(5)$ & $--(5)$ & $--(5)$ & $--(5)$ & $--(5)$ & $--(5)$ \\
\hline B255 & B255 & $4.6(\mathrm{~L}, \mathrm{~B})$ & $--(5)$ & $--(20)$ & $-(5)$ & $--(5)$ & $--(5)$ & $--(5)$ & $--(5)$ & $--(5)$ & $--(5)$ \\
\hline B254 & B254 & 14 & $--(5)$ & $6.7(\mathrm{~L})$ & $--(5)$ & $--(5)$ & $--(5)$ & $1.4(\mathrm{~L})$ & $--(5)$ & 7.6 & $--(5)$ \\
\hline RAP1-7 & RAP1-7-A & 15 & $--(5)$ & $8.1(\mathrm{~L})$ & $--(5)$ & $--(5)$ & $--(5)$ & 5.1 & $--(5)$ & 56 & $--(5)$ \\
\hline RAP1-7 & RAP1-7-B & $75(\mathrm{~L}, \mathrm{~B})$ & $--(100)$ & $--(400)$ & $--(100)$ & $--(100)$ & $--(100)$ & $--(100)$ & $--(100)$ & 280 & $--(100)$ \\
\hline RAP1-7 & RAP1-7-C & $70(\mathrm{~L}, \mathrm{~B})$ & $--(50)$ & $--(200)$ & $--(50)$ & $--(50)$ & $--(50)$ & $--(50)$ & $--(50)$ & 180 & $--(50)$ \\
\hline RAP1-7 & RAP1-7-D & $--(100)$ & $--(50)$ & $--(200)$ & $--(50)$ & $--(50)$ & $-(50)$ & $--(50)$ & $--(50)$ & 220 & $--(50)$ \\
\hline RAP1-7 & RAP1-7-E & $25(\mathrm{~L}, \mathrm{~B})$ & $--(25)$ & $--(100)$ & $--(25)$ & $-(25)$ & $--(25)$ & $9.7(\mathrm{~L})$ & $--(25)$ & 190 & $-(25)$ \\
\hline B126 & B126-A & $5.2(\mathrm{~L}, \mathrm{~B})$ & $--(5)$ & $-(20)$ & $--(5)$ & $-(5)$ & $--(5)$ & 8.4 & $--(5)$ & 15 & $--(5)$ \\
\hline B126 & B126-B & $5.8(\mathrm{~L}, \mathrm{~B})$ & $--(5)$ & $--(20)$ & $--(5)$ & $--(5)$ & $--(5)$ & 14 & $--(5)$ & 22 & $--(5)$ \\
\hline B126 & B126-C & 4.1(L,B) & $--(5)$ & $--(20)$ & $-(5)$ & $-(5)$ & $--(5)$ & 11 & $--(5)$ & 20 & $-(5)$ \\
\hline B111 & B111-A & 14 & $--(5)$ & 7.1(L) & $--(5)$ & $--(5)$ & $--(5)$ & 7.8 & $--(5)$ & 65 & $--(5)$ \\
\hline B111 & B111-B & $8.1(\mathrm{~L}, \mathrm{~B})$ & $--(5)$ & $--(20)$ & $--(5)$ & $--(5)$ & $--(5)$ & 8.2 & $--(5)$ & 85 & $--(5)$ \\
\hline B111 & B111-C & $19(\mathrm{~B})$ & $--(5)$ & $--(20)$ & $-(5)$ & $--(5)$ & $--(5)$ & 9.1 & $--(5)$ & 77 & $--(5)$ \\
\hline B244A & B244A-A & 15 & $--(5)$ & $--(20)$ & $--(5)$ & $--(5)$ & $--(5)$ & 63 & $-(5)$ & 8.1 & $1.6(\mathrm{~L})$ \\
\hline B244A & B244A-B & $11(\mathrm{~B})$ & $--(5)$ & $--(20)$ & $-(5)$ & $--(5)$ & $--(5)$ & 65 & $--(5)$ & 5 & $2.0(\mathrm{~L})$ \\
\hline B244A & B244A-C & 15 & $--(5)$ & $--(20)$ & $--(5)$ & $--(5)$ & $--(5)$ & 55 & $--(5)$ & 47 & $1.2(\mathrm{~L})$ \\
\hline B244A & B244A-D & $11(\mathrm{~B})$ & $--(5)$ & $--(20)$ & $-(5)$ & $--(5)$ & $--(5)$ & 61 & $-(5)$ & 46 & $1.3(\mathrm{~L})$ \\
\hline B244A & B244A-E & $-(10)$ & $--(5)$ & $--(20)$ & $-(5)$ & $--(5)$ & $--(5)$ & 82 & $--(5)$ & 19 & $1.7(\mathrm{~L})$ \\
\hline B245 & B245 & $11(\mathrm{~B})$ & $--(5)$ & $-(20)$ & $--(5)$ & $--(5)$ & $--(5)$ & 15 & $--(5)$ & 7.4 & $--(5)$ \\
\hline B251 & B251 & 15 & $--(5)$ & $--(20)$ & $-(5)$ & $-(5)$ & $--(5)$ & $1(\mathrm{~L})$ & $--(5)$ & 18 & $--(5)$ \\
\hline B249 & B249 & $10(B)$ & $--(5)$ & $--(20)$ & $--(5)$ & $--(5)$ & $--(5)$ & $2.9(\mathrm{~L})$ & $1.1(\mathrm{~L})$ & 35 & $--(5)$ \\
\hline B248 & B248 & $180(\mathrm{~L})$ & $--(100)$ & $--(400)$ & $--(100)$ & $--(100)$ & $--(100)$ & 170 & $-(100)$ & 470 & $--(100)$ \\
\hline B113 & B113-A & 16 & $--(5)$ & $--(20)$ & $--(5)$ & $3.6(\mathrm{~L})$ & $2.7(\mathrm{~L})$ & 98 & $--(5)$ & 32 & 8.2 \\
\hline B113 & B113-B & $5.9(\mathrm{~L}, \mathrm{~B})$ & $--(5)$ & $--(20)$ & $--(5)$ & $3.6(\mathrm{~L})$ & $2.3(\mathrm{~L})$ & 100 & $--(5)$ & 30 & 6.6 \\
\hline B113 & B113-C & $6.7(L, B)$ & $--(5)$ & $--(20)$ & $--(5)$ & $3.0(\mathrm{~L})$ & $1.9(\mathrm{~L})$ & 99(L) & $--(5)$ & 34 & 5.4 \\
\hline PO2-2R & PO2-2R-A & $5.2(\mathrm{~L}, \mathrm{~B})$ & $--(5)$ & $--(20)$ & $--(5)$ & $--(5)$ & $--(5)$ & 10 & $--(5)$ & 43 & $--(5)$ \\
\hline PO2-2R & PO2-2R-B & $6.3(\mathrm{~L}, \mathrm{~B})$ & $--(5)$ & $--(20)$ & $--(5)$ & $--(5)$ & $--(5)$ & 12 & $-(5)$ & 48 & $--(5)$ \\
\hline PO2-2R & PO2-2R-C & 5.7(L,B) & $--(5)$ & $--(20)$ & $--(5)$ & $--(5)$ & $--(5)$ & 16 & $--(5)$ & 56 & $--(5)$ \\
\hline PO2-2R & PO2-2R-D & $10(\mathrm{~B})$ & $1.9(\mathrm{~L})$ & $-(20)$ & $--(5)$ & $2.1(\mathrm{~L})$ & $3.2(\mathrm{~L})$ & 140 & $--(5)$ & 350 & $--(5)$ \\
\hline PO2-2R & PO2-2R-E & $23(L, B)$ & $1.9(\mathrm{~L})$ & $--(20)$ & $--(5)$ & $2.3(\mathrm{~L})$ & $2.4(\mathrm{~L})$ & 140 & $--(5)$ & 320 & $--(5)$ \\
\hline RAP2-3T & RAP2-3T-A & $21(\mathrm{~L}, \mathrm{~B})$ & $--(25)$ & $-(100)$ & $--(25)$ & $-(25)$ & $--(25)$ & 170 & $--(25)$ & 160 & $--(25)$ \\
\hline RAP2-3T & RAP2-3T-B & $--(50)$ & $--(25)$ & $-(100)$ & $--(25)$ & $--(25)$ & $-(25)$ & $14(\mathrm{~L})$ & $--(25)$ & 86 & $--(25)$ \\
\hline RAP2-3T & RAP2-3T-C & $--(50)$ & $--(25)$ & $--(100)$ & $--(25)$ & $--(25)$ & $--(25)$ & 35 & $--(25)$ & 200 & $--(25)$ \\
\hline RAP2-3T & RAP2-3T-D & $--(50)$ & $--(25)$ & $--(100)$ & $--(25)$ & $-(25)$ & $--(25)$ & 28 & $--(25)$ & 160 & $--(25)$ \\
\hline RAP2-3T & RAP2-3T-E & $--(50)$ & $--(25)$ & $--(100)$ & $--(25)$ & $--(25)$ & $--(25)$ & $13(\mathrm{~L})$ & $--(25)$ & 71 & $--(25)$ \\
\hline
\end{tabular}


Table 3. Concentrations of volatile organic compounds in ground-water samples collected with water diffusion samplers from wells at Hanscom Air Force Base, Bedford, Mass., May 10-13, 1999-Continued

\begin{tabular}{|c|c|c|c|c|c|c|c|c|c|c|c|}
\hline \multirow[b]{2}{*}{$\begin{array}{c}\text { Well } \\
\text { name }\end{array}$} & \multirow[b]{2}{*}{$\begin{array}{l}\text { Water } \\
\text { diffusion } \\
\text { sampler } \\
\text { name }\end{array}$} & \multicolumn{10}{|c|}{ Volatile organic compounds in micrograms per liter } \\
\hline & & Acetone & Benzene & 2-Butanone & $\begin{array}{l}\text { Chloro- } \\
\text { methane }\end{array}$ & $\begin{array}{c}\text { 1,1- } \\
\text { Dichloro- } \\
\text { ethane }\end{array}$ & $\begin{array}{c}\text { 1,1- } \\
\text { Dichloro- } \\
\text { ethylene }\end{array}$ & $\begin{array}{l}\text { 1,2- } \\
\text { Dichloro- } \\
\text { ethylene } \\
\text { isomers }\end{array}$ & Toluene & $\begin{array}{l}\text { Trichloro } \\
\text {-ethylene }\end{array}$ & $\begin{array}{c}\text { Vinyl } \\
\text { chloride }\end{array}$ \\
\hline B108 & B108-A & $33(\mathrm{~L}, \mathrm{~B})$ & $--(5)$ & $--(20)$ & $--(5)$ & $-(5)$ & $-(5)$ & 22 & $-(5)$ & 21 & $--(5)$ \\
\hline B108 & B108-B & 3.1(L,B) & $--(5)$ & $--(20)$ & $--(5)$ & $--(5)$ & $--(5)$ & 25 & $-(5)$ & 12 & $--(5)$ \\
\hline B108 & B108-C & $35(\mathrm{~L}, \mathrm{~B})$ & $--(5)$ & $--(20)$ & $--(5)$ & $--(5)$ & $--(5)$ & 26 & $--(5)$ & 14 & $--(5)$ \\
\hline RAP2-1R & RAP2-1R-A & $--(50)$ & $--(25)$ & $-(100)$ & $--(25)$ & $5.2(\mathrm{~L})$ & $--(25)$ & 340 & $--(25)$ & -840 & $--(25)$ \\
\hline RAP2-1R & RAP2-1R-B & $40(\mathrm{~L}, \mathrm{~B})$ & $--(25)$ & $--(100)$ & $--(25)$ & $--(25)$ & $7.8(\mathrm{~L})$ & 300 & $--(25)$ & 890 & $--(25)$ \\
\hline RAP2-1R & RAP2-1R-C & $26(L, B)$ & $--(25)$ & $--(100)$ & $-(25)$ & $5.9(\mathrm{~L})$ & $--(25)$ & 270 & $--(25)$ & 780 & $-(25)$ \\
\hline RAP2-1R & RAP2-1R-D & $21(\mathrm{~L}, \mathrm{~B})$ & $--(25)$ & $--(100)$ & $--(25)$ & $5.9(\mathrm{~L})$ & $--(25)$ & 280 & $--(25)$ & 540 & $--(25)$ \\
\hline RAP2-1R & RAP2-1R-E & $49(\mathrm{~L}, \mathrm{~B})$ & $--(25)$ & $--(100)$ & $--(25)$ & $4.8(\mathrm{~L})$ & $--(25)$ & 260 & $--(25)$ & 490 & $--(25)$ \\
\hline RAP2-1T & RAP2-1T-A & 21(L,B) & $--(25)$ & $--(100)$ & $--(25)$ & $--(25)$ & $--(25)$ & $--(25)$ & $--(25)$ & 55 & $--(25)$ \\
\hline RAP2-1T & RAP2-1T-B & $24(\mathrm{~L}, \mathrm{~B})$ & $--(25)$ & $--(100)$ & $--(25)$ & $--(25)$ & $--(25)$ & $15(L)$ & $--(25)$ & 230 & $--(25)$ \\
\hline RAP2-1T & RAP2-1T-C & $--(50)$ & 4.4(L) & $--(100)$ & $--(25)$ & $--(25)$ & $--(25)$ & 95 & $-(25)$ & 900 & $--(25)$ \\
\hline RAP2-1T & RAP2-1T-D & $31(\mathrm{~B})$ & $--(5)$ & $--(20)$ & $--(5)$ & $3.8(\mathrm{~L})$ & $--(5)$ & 82 & $-(5)$ & 1300 & $--(5)$ \\
\hline RAP2-1T & RAP2-1T-E & $--(50)$ & $5.0(\mathrm{~L})$ & $--(100)$ & $--(25)$ & $--(25)$ & $--(25)$ & 97 & $--(25)$ & 990 & $--(25)$ \\
\hline RAP2-2R & RAP2-2R-A & $26(B)$ & $-(25)$ & $--(100)$ & $--(25)$ & 54 & 30 & 1400 & $--(25)$ & 320 & 120 \\
\hline RAP2-2R & RAP2-2R-B & $36(L)$ & $--(25)$ & $-(100)$ & $--(25)$ & 57 & 34 & 1800 & $-(25)$ & 300 & 160 \\
\hline RAP2-2R & RAP2-2R-C & $33(\mathrm{~B})$ & $--(25)$ & $--(100)$ & $--(25)$ & 51 & 29 & 1800 & $--(25)$ & 280 & 140 \\
\hline RAP2-2R & RAP2-2R-D & $28(\mathrm{~L}, \mathrm{~B})$ & $--(25)$ & $--(100)$ & $--(25)$ & 57 & 37 & 1800 & $--(25)$ & 270 & 140 \\
\hline RAP2-2R & RAP2-2R-E & $43(\mathrm{~L}, \mathrm{~B})$ & $--(25)$ & $--(100)$ & $--(25)$ & 61 & 37 & 1900 & $--(25)$ & 350 & 150 \\
\hline RAP1-6T & RAP1-6T-A & $--(500)$ & $-(250)$ & $--(1000)$ & $--(250)$ & $82(L)$ & $--(250)$ & 2400 & $--(250)$ & 410 & $180(\mathrm{~L})$ \\
\hline RAP1-6T & RAP1-6T-B & $-(500)$ & $--(250)$ & $--(1000)$ & $--(250)$ & 280 & $140(\mathrm{~L})$ & 6800 & $--(250)$ & 1600 & 1600 \\
\hline RAP1-6T & RAP1-6T-C & $330(\mathrm{~L}, \mathrm{~B})$ & $--(250)$ & $--(1000)$ & $--(250)$ & 250 & $140(L)$ & $6800(E)$ & $--(250)$ & 1600 & 1300 \\
\hline RAP1-6T & RAP1-6T-D & $230(\mathrm{~L}, \mathrm{~B})$ & $--(250)$ & $--(1000)$ & $-(250)$ & 270 & $140(\mathrm{~L})$ & $6600(E)$ & $-(250)$ & 1800 & 1300 \\
\hline RAP1-6T & RÄP1-6T-E & $--(500)$ & $--(250)$ & $--(1000)$ & $--(250)$ & $200(\mathrm{~L})$ & $110(\mathrm{~L})$ & $6200(E)$ & $--(250)$ & 1600 & 1200 \\
\hline RAP1-6R & RAP1-6R-A & $--(500)$ & $--(250)$ & $--(1000)$ & $--(250)$ & $200(L)$ & $--(250)$ & $5100(\mathrm{E})$ & $--(250)$ & 1000 & 940 \\
\hline RAP1-6R & RAP1-6R-B & $180(\mathrm{~L}, \mathrm{~B})$ & $--(250)$ & $--(1000)$ & $--(250)$ & $200(L)$ & $110(\mathrm{~L})$ & $5400(\mathrm{E})$ & $--(250)$ & 1100 & 930 \\
\hline RAP1-6R & RAP1-6R-C & $--(500)$ & $--(250)$ & $--(1000)$ & $--(250)$ & $230(\mathrm{~L})$ & $110(\mathrm{~L})$ & $6400(E)$ & $--(250)$ & 1400 & 1100 \\
\hline RAP1-6R & RAP1-6R-D & $--(500)$ & $--(250)$ & $--(1000)$ & $--(250)$ & $220(\mathrm{~L})$ & $--(250)$ & $6300(\mathrm{E})$ & $--(250)$ & 1300 & 1300 \\
\hline RAP1-6R & RAP1-6R-E & $--(500)$ & $--(250)$ & $--(1000)$ & $--(250)$ & $200(L)$ & $-(250)$ & 5400 & $--(250)$ & 1100 & 930 \\
\hline B240 & B240-A & $--(500)$ & $--(500)$ & $--(2000)$ & $-(500)$ & $140(L)$ & $--(500)$ & $2200(B)$ & $--(500)$ & 4400 & $220(\mathrm{~L})$ \\
\hline B240 & B240-B & $--(500)$ & $--(500)$ & $--(2000)$ & $--(500)$ & $190(\mathrm{~L})$ & $--(500)$ & 2500 & $--(500)$ & 4900 & $270(\mathrm{~L})$ \\
\hline B240 & B240-C & $--(500)$ & $--(500)$ & $--(2000)$ & $-(500)$ & $200(\mathrm{~L})$ & $--(500)$ & 2500 & $--(500)$ & 4600 & $280(\mathrm{~L})$ \\
\hline
\end{tabular}


Table 4. Concentrations of volatile organic compounds in ground-water samples collected with a low-flow sampling method from wells at Hanscom Air Force Base, Bedford, Mass., May 10-14, 1999

[B, analyte found in lab blank; E, estimated value exceeds calibration range; L, estimated value is below calibration range; --(5), not detected at reporting limit of 5 micrograms per liter]

\begin{tabular}{|c|c|c|c|c|c|c|c|c|c|c|}
\hline \multirow[b]{2}{*}{$\begin{array}{l}\text { Well } \\
\text { name }\end{array}$} & \multicolumn{10}{|c|}{ Volatile organic compounds in micrograms per liter } \\
\hline & Acetone & Benzene & 2-Butanone & $\begin{array}{c}\text { 1,1- } \\
\text { Dichloro- } \\
\text { ethane }\end{array}$ & $\begin{array}{l}\text { 1,1- } \\
\text { Dichloro- } \\
\text { ethylene }\end{array}$ & $\begin{array}{l}\text { 1,2-Dichloro- } \\
\text { ethylene } \\
\text { isomers }\end{array}$ & $\begin{array}{c}\text { Methylene } \\
\text { chloride }\end{array}$ & Toluene & $\begin{array}{l}\text { Trichloro- } \\
\text { ethylene }\end{array}$ & $\begin{array}{c}\text { Vinyl } \\
\text { chloride }\end{array}$ \\
\hline A-3 & $--(10)$ & $--(5)$ & $--(20)$ & $--(5)$ & $-(5)$ & $-(5)$ & 8.0 & $--(5)$ & $-(5)$ & $--(5)$ \\
\hline RAP1-6S & $3.9(\mathrm{~L}, \mathrm{~B})$ & $--(5)$ & $--(20)$ & $--(5)$ & $-(5)$ & 12 & $--(5)$ & $--(5)$ & $2.8(\mathrm{~L})$ & $--(5)$ \\
\hline B107 & $5.5(\mathrm{~L}, \mathrm{~B})$ & $--(5)$ & $-(20)$ & $--(5)$ & $-(5)$ & $--(5)$ & $-(5)$ & $--(5)$ & $--(5)$ & $--(5)$ \\
\hline B255 & $--(10)$ & $--(5)$ & $--(20)$ & $--(5)$ & $--(5)$ & $--(5)$ & $-(5)$ & $--(5)$ & $--(5)$ & $--(5)$ \\
\hline B254 & $7.2(\mathrm{~L}, \mathrm{~B})$ & $--(5)$ & $--(20)$ & $--(5)$ & $--(5)$ & $--(5)$ & $--(5)$ & $--(5)$ & $2.6(\mathrm{~L})$ & $--(5)$ \\
\hline RAP1-7 & $37(\mathrm{~L})$ & $--(25)$ & $--(100)$ & $--(25)$ & $--(25)$ & $8.2(\mathrm{~L})$ & $--(25)$ & $--(25)$ & 180 & $--(25)$ \\
\hline B126 & $4.9(\mathrm{~L}, \mathrm{~B})$ & $-(5)$ & $--(20)$ & $--(5)$ & $--(5)$ & 11 & $--(5)$ & $--(5)$ & 19 & $--(5)$ \\
\hline B111 & $--(10)$ & $--(5)$ & $--(20)$ & $--(5)$ & $--(5)$ & 5.9 & $--(5)$ & $--(5)$ & 47 & $--(5)$ \\
\hline B251 & $--(10)$ & $--(5)$ & $--(20)$ & $--(5)$ & $--(5)$ & $4.3(\mathrm{~L})$ & $--(5)$ & $--(5)$ & 22 & $--(5)$ \\
\hline B249 & 16 & $--(5)$ & $--(20)$ & $--(5)$ & $--(5)$ & $--(5)$ & $--(5)$ & $--(5)$ & 18 & $--(5)$ \\
\hline B248 & $26(\mathrm{~L}, \mathrm{~B})$ & $--(25)$ & $--(100)$ & $--(25)$ & $--(25)$ & 130 & $--(25)$ & $--(25)$ & 260 & $--(25)$ \\
\hline B113 & $--(10)$ & $--(5)$ & $--(20)$ & $1.1(\mathrm{~L})$ & $--(5)$ & 51 & $--(5)$ & $--(5)$ & 11 & $1.9(\mathrm{~L})$ \\
\hline $\mathrm{PO} 2-2 \mathrm{R}$ & $--(50)$ & $--(25)$ & $-(100)$ & $--(25)$ & $--(25)$ & 25 & $--(25)$ & $--(25)$ & 68 & $--(25)$ \\
\hline RAP2-3T & $--(50)$ & $--(25)$ & $--(100)$ & $--(25)$ & $--(25)$ & 77 & $--(25)$ & $--(25)$ & 170 & $--(25)$ \\
\hline B108 & $7.7(\mathrm{~L}, \mathrm{~B})$ & $--(5)$ & $--(20)$ & $--(5)$ & $--(5)$ & 7.4 & $--(5)$ & $--(5)$ & 16 & $--(5)$ \\
\hline RAP2-1R & $--(50)$ & $--(25)$ & $--(100)$ & $--(25)$ & $--(25)$ & 470 & $--(25)$ & $--(25)$ & 750 & $--(25)$ \\
\hline RAP2-1T & $--(500)$ & $--(250)$ & $-(1000)$ & $--(250)$ & $--(250)$ & $--(250)$ & $--(250)$ & $--(250)$ & 880 & $--(250)$ \\
\hline RAP2-2R & $230(\mathrm{~L}, \mathrm{~B})$ & $--(250)$ & $-(1000)$ & $--(250)$ & $--(250)$ & 2200 & $--(250)$ & $--(250)$ & 190 & $150(\mathrm{~L})$ \\
\hline RAP1-6T & $--(500)$ & $--(250)$ & $--(1000)$ & 250 & $--(250)$ & $6200(E)$ & $--(250)$ & $--(250)$ & 1500 & 1300 \\
\hline RAP1-6R & $--(500)$ & $--(250)$ & $--(1000)$ & $230(\mathrm{~L})$ & $100(\mathrm{~L})$ & $6400(E)$ & $--(250)$ & $--(250)$ & 1200 & 810 \\
\hline $\mathrm{B} 240$ & $--(500)$ & $--(500)$ & $--(1000)$ & $210(\mathrm{~L})$ & $--(250)$ & 2600 & $--(250)$ & $--(500)$ & 4900 & $280(\mathrm{~L})$ \\
\hline
\end{tabular}


Table 5. Concentrations of volatile organic compounds in duplicate ground-water samples collected with water diffusion samplers and a low-flow sampling method from wells at Hanscom Air Force Base, Bedford, Mass., May 10-14, 1999

[B, analyte found in lab blank; Dup, duplicate; E, estimated value exceeds calibration range; L, estimated value is below calibration range; --(5), not detected at reporting limit of 5 micrograms per liter]

\begin{tabular}{|c|c|c|c|c|c|c|c|c|c|c|c|c|c|}
\hline \multirow{3}{*}{$\begin{array}{c}\text { Well and } \\
\text { diffusion } \\
\text { sampler } \\
\text { name }\end{array}$} & \multirow{3}{*}{$\begin{array}{l}\text { Sampling } \\
\text { method }\end{array}$} & \multicolumn{12}{|c|}{ Volatile organic compounds in micrograms per liter } \\
\hline & & \multicolumn{2}{|c|}{ Acetone } & \multicolumn{2}{|c|}{$\begin{array}{l}\text { 1,1-Dichloro- } \\
\text { ethane }\end{array}$} & \multicolumn{2}{|c|}{$\begin{array}{l}\text { 1,1-Dichloro- } \\
\text { ethylene }\end{array}$} & \multicolumn{2}{|c|}{$\begin{array}{l}\text { 1,2-Dichloro- } \\
\text { ethylene } \\
\text { Isomers }\end{array}$} & \multicolumn{2}{|c|}{$\begin{array}{l}\text { Trichloro- } \\
\text { ethylene }\end{array}$} & \multicolumn{2}{|c|}{ Vinyl chloride } \\
\hline & & Sample & Dup & Sample & Dup & Sample & Dup & Sample & Dup & Sample & Dup & Sample & Dup \\
\hline B111-B & Diffusion & $8.1(\mathrm{~L}, \mathrm{~B})$ & $5.7(\mathrm{~L}, \mathrm{~B})$ & $--(5)$ & $--(5)$ & $-(5)$ & $--(5)$ & 8.2 & 8.9 & 85 & 84 & $--(5)$ & $--(5)$ \\
\hline B245 & Diffusion & 11(B) & $10(B)$ & $-(5)$ & $-(5)$ & $-(5)$ & $--(5)$ & 15 & 15 & 7.4 & 7.1 & $--(5)$ & $-(5)$ \\
\hline B113-B & Diffusion & $5.9(\mathrm{~L}, \mathrm{~B})$ & $6.0(\mathrm{~L}, \mathrm{~B})$ & $3.6(\mathrm{~L})$ & $3.1(\mathrm{~L})$ & $2.3(\mathrm{~L})$ & $28(\mathrm{~L})$ & 100 & 92 & 30 & 32 & 6.6 & 6.1 \\
\hline RAP2-1R-C & Diffusion & $26(\mathrm{~L}, \mathrm{~B})$ & $23(\mathbf{L}, \mathrm{B})$ & $59(\mathrm{~L})$ & $4.4(\mathrm{~L})$ & $--(25)$ & $--(25)$ & 270 & 250 & 780 & 790 & $--(25)$ & $--(25)$ \\
\hline RAP1-6R-C & Diffusion & $-(250)$ & $210(\mathrm{~L}, \mathrm{~B})$ & $230(\mathrm{~L})$ & $200(\mathrm{~L})$ & $110(\mathrm{~L})$ & $110(\mathrm{~L})$ & $6,400(\mathrm{E})$ & $6,100(E)$ & 1,400 & 1,200 & 1100 & 1200 \\
\hline B254 & Low-Flow & 7.2(L,B) & $2.3(\mathrm{~L}, \mathrm{~B})$ & $--(5)$ & $-(5)$ & $-(5)$ & $--(5)$ & $--(5)$ & $--(5)$ & $2.6(\mathrm{~L})$ & $22(\mathrm{~L})$ & $-(5)$ & $-(5)$ \\
\hline RAP1-6R & Low-Flow & $-(500)$ & $--(500)$ & $230(\mathrm{~L})$ & $230(\mathrm{~L})$ & $100(\mathrm{~L})$ & $120(\mathrm{~L})$ & $6,400(E)$ & $5,700(\mathrm{E})$ & 1,200 & 1,300 & 810 & 810 \\
\hline B240 & Low-Flow & $--(500)$ & $--(500)$ & $210(\mathrm{~L})$ & $160(\mathrm{~L})$ & $--(250)$ & $--(250)$ & 2600 & 2600 & 4900 & 4800 & $280(\mathrm{~L})$ & $250(\mathrm{~L})$ \\
\hline
\end{tabular}

Table 6. Concentrations of volatile organic compounds in trip and equipment blank samples, Hanscom Air Force Base, Bedford, Mass., May 10-14, 1999

[B, analyte found in lab blank; L, estimated value is below calibration range; - - (5), not detected at reporting limit of 5 micrograms per liter]

\begin{tabular}{|c|c|c|c|c|c|c|c|c|c|c|}
\hline \multirow[b]{2}{*}{ Blank } & \multirow[b]{2}{*}{$\begin{array}{l}\text { Sampling } \\
\text { method }\end{array}$} & \multirow[b]{2}{*}{ Date } & \multirow{2}{*}{$\begin{array}{c}\text { Time } \\
\text { sampled } \\
\text { (for equip- } \\
\text { ment } \\
\text { blanks) }\end{array}$} & \multicolumn{7}{|c|}{ Volatile organic compounds in micrograms per liter } \\
\hline & & & & Acetone & $\begin{array}{c}\text { 1,1- } \\
\text { Dichloro- } \\
\text { ethane }\end{array}$ & $\begin{array}{c}\text { 1,1- } \\
\text { Dichloro- } \\
\text { ethylene }\end{array}$ & $\begin{array}{l}1,2- \\
\text { Dichloro- } \\
\text { ethylene } \\
\text { isomers }\end{array}$ & 2-Hexanone & $\begin{array}{l}\text { Trichloro- } \\
\text { ethylene }\end{array}$ & $\begin{array}{l}\text { Vinyl } \\
\text { chloride }\end{array}$ \\
\hline Trip & Diffusion & $5 / 10 / 1999$ & & $-(10)$ & $-(5)$ & $-(5)$ & $--(5)$ & $--(3)$ & $-(5)$ & $--(5)$ \\
\hline Trip & Diffusion & $5 / 11 / 1999$ & & $5.8(\mathrm{~L}, \mathrm{~B})$ & $-(5)$ & $-(5)$ & $--(5)$ & $-(3)$ & $-(5)$ & $-(5)$ \\
\hline Trip & Diffusion & $5 / 12 / 1999$ & & $--(10)$ & $-(5)$ & $--(5)$ & $-(5)$ & $-(3)$ & $-(5)$ & $--(5)$ \\
\hline Trip & Diffusion & $5 / 13 / 1999$ & & $8.4(\mathrm{~L}, \mathrm{~B})$ & $-(5)$ & $--(5)$ & $-(5)$ & $2.3(\mathrm{~L}, \mathrm{~B})$ & $-(5)$ & $--(5)$ \\
\hline Trip & Low-flow & $5 / 14 / 1999$ & & $5.8(\mathrm{~L}, \mathrm{~B})$ & $--(5)$ & $--(5)$ & $--(5)$ & $-(3)$ & $-(5)$ & $-(5)$ \\
\hline Equipment & Diffusion & $5 / 10 / 1999$ & 0730 & $--(10)$ & $--(5)$ & $--(5)$ & $--(5)$ & $-(3)$ & $--(5)$ & $--(5)$ \\
\hline Equipment & Low-flow & $5 / 10 / 1999$ & 1450 & 20 & $-(5)$ & $--(5)$ & $--(5)$ & $-(3)$ & $--(5)$ & $--(5)$ \\
\hline Equipment & Low-flow & $5 / 11 / 1999$ & 1540 & $-(10)$ & $-(5)$ & $-(5)$ & $--(5)$ & $-(3)$ & $-(5)$ & $-(5)$ \\
\hline Equipment & Low-flow & $5 / 12 / 1999$ & 1630 & $6.9(\mathrm{~L}, \mathrm{~B})$ & $--(5)$ & $--(5)$ & $-(5)$ & $--(3)$ & $--(5)$ & $--(5)$ \\
\hline Equipment & Low-flow & $5 / 13 / 1999$ & 1415 & $7.2(\mathrm{~L}, \mathrm{~B})$ & $-(5)$ & $--(5)$ & $--(5)$ & $-(3)$ & $--(5)$ & $--(5)$ \\
\hline Equipment & Low-flow & $5 / 14 / 1999$ & 1330 & $9.4(\mathrm{~L}, \mathrm{~B})$ & $-(5)$ & $-(5)$ & 12 & $-(3)$ & 56 & $2.6(\mathrm{~L})$ \\
\hline
\end{tabular}


Table 7. Vertical flow in four screened wells and one open borehole, Hanscom Air Force Base, Bedford, Mass., June 1-4, 1999 [bls, below land surface; ft, foot; gal/min, gallons per minute; -, indicates downward flow; + , indicates upward flow]

\begin{tabular}{|c|c|c|c|c|c|c|c|c|c|c|}
\hline \multirow{2}{*}{$\begin{array}{c}\text { Well } \\
\text { name }\end{array}$} & \multirow{2}{*}{$\begin{array}{l}\text { Geologic } \\
\text { unit } \\
\text { screened }\end{array}$} & \multicolumn{3}{|c|}{$\begin{array}{c}\text { Reported well screen or } \\
\text { open borehole data } \\
\text { (ft bls) }\end{array}$} & \multirow{2}{*}{$\begin{array}{l}\text { Measured } \\
\text { depth of } \\
\text { well } \\
\text { (ft bls) }\end{array}$} & \multicolumn{2}{|c|}{$\begin{array}{l}\text { Vertical flow } \\
\text { measurements under } \\
\text { static condition }\end{array}$} & \multicolumn{3}{|c|}{$\begin{array}{l}\text { Vertical flow measurements under } \\
\text { pumping conditions }\end{array}$} \\
\hline & & Length & Top & Bottom & & $\begin{array}{l}\text { Depth of } \\
\text { measurement } \\
\text { (ft bls) }\end{array}$ & $\begin{array}{c}\text { Flow } \\
\text { (gal/min) }\end{array}$ & $\begin{array}{l}\text { Pumping } \\
\text { rate } \\
\text { (gal/min) }\end{array}$ & $\begin{array}{l}\text { Depth of } \\
\text { measurement } \\
\text { (ft bls) }\end{array}$ & $\begin{array}{c}\text { Flow } \\
\text { (gal/min) }\end{array}$ \\
\hline \multirow[t]{14}{*}{ PO2-2R } & Bedrock & 30 & 102.5 & 132.5 & 132.2 & 93.2 & -0.014 & 0.35 & 92.9 & +0.381 \\
\hline & & & & & & 103.9 & -0.014 & & 102.9 & +0.381 \\
\hline & & & & & & 109.0 & -0.013 & & 103.8 & +0.410 \\
\hline & & & & & & 114.0 & -0.007 & & 105.9 & +0.410 \\
\hline & & & & & & 118.9 & 0 & & 108.9 & +0.381 \\
\hline & & & & & & 123.9 & 0 & & 111.0 & +0.410 \\
\hline & & & & & & & & & 113.9 & +0.356 \\
\hline & & & & & & & & & 117.8 & +0.279 \\
\hline & & & & & & & & & 120.0 & +0.084 \\
\hline & & & & & & & & & 121.0 & +0.043 \\
\hline & & & & & & & & & 122.0 & +0.016 \\
\hline & & & & & & & & & 123.0 & +0.006 \\
\hline & & & & & & & & & 125.9 & 0 \\
\hline & & & & & & & & & 129.0 & 0 \\
\hline \multirow[t]{7}{*}{ RAP2-1T } & Till & 20.7 & 58.3 & 79.0 & 77.0 & 62.9 & -0.008 & 0.6 & 55.9 & +0.637 \\
\hline & & & & & & 65.5 & -0.030 & & 60.4 & +0.576 \\
\hline & & & & & & 68.0 & -0.052 & & 62.9 & +0.576 \\
\hline & & & & & & 70.4 & -0.059 & & 65.7 & +0.443 \\
\hline & & & & & & 72.9 & -0.049 & & 67.9 & +0.356 \\
\hline & & & & & & 73.9 & -0.046 & & 70.4 & +0.269 \\
\hline & & & & & & 75.4 & -0.031 & & 73.9 & +0.208 \\
\hline \multirow[t]{9}{*}{ RAP2-1R } & Bedrock & 16.5 & 106.0 & 122.5 & 122.2 & 95.6 & -0.008 & 0.6 & 105.4 & +0.045 \\
\hline & Open hole & & & & & 102.4 & -0.009 & & 107.4 & +0.014 \\
\hline & & & & & & 104.5 & -0.008 & & 112.4 & +0.009 \\
\hline & & & & & & 105.8 & -0.008 & & 115.0 & +0.007 \\
\hline & & & & & & 106.4 & 0 & & 115.9 & +0.006 \\
\hline & & & & & & 107.5 & 0 & & 116.7 & +0.006 \\
\hline & & & & & & 112.5 & 0 & & 120.9 & 0 \\
\hline & & & & & & 117.4 & 0 & & & \\
\hline & & & & & & 120.9 & 0 & & & \\
\hline \multirow[t]{9}{*}{ RAP1-6T } & Till & 15.1 & 29.6 & 44.7 & 45.0 & 30.4 & +0.007 & 0.6 & 27.8 & +0.576 \\
\hline & & & & & & 32.3 & +0.007 & & 30.3 & +0.576 \\
\hline & & & & & & 34.3 & +0.021 & & 32.4 & +0.576 \\
\hline & & & & & & 36.4 & +0.021 & & 34.4 & +0.576 \\
\hline & & & & & & 38.6 & +0.026 & & 36.4 & +0.525 \\
\hline & & & & & & 40.3 & +0.027 & & 38.4 & +0.524 \\
\hline & & & & & & 42.5 & +0.025 & & 40.3 & +0.524 \\
\hline & & & & & & 43.4 & +0.021 & & 42.4 & +0.443 \\
\hline & & & & & & 43.6 & +0.019 & & 43.6 & +0.356 \\
\hline
\end{tabular}


Table 7. Vertical flow in four screened wells and one open borehole, Hanscom Air Force Base, Bedford, Mass., June 1-4, 1999

\begin{tabular}{|c|c|c|c|c|c|c|c|c|c|c|}
\hline \multirow{2}{*}{$\begin{array}{c}\text { Well } \\
\text { name }\end{array}$} & \multirow{2}{*}{$\begin{array}{l}\text { Geologic } \\
\text { unit } \\
\text { screened }\end{array}$} & \multicolumn{3}{|c|}{$\begin{array}{l}\text { Reported well screen or } \\
\text { open borehole data } \\
\text { (ft bls) }\end{array}$} & \multirow{2}{*}{$\begin{array}{c}\text { Measured } \\
\text { depth of } \\
\text { well } \\
\text { (ft bls) }\end{array}$} & \multicolumn{2}{|c|}{$\begin{array}{l}\text { Vertical flow } \\
\text { measurements under } \\
\text { static condition }\end{array}$} & \multicolumn{3}{|c|}{$\begin{array}{l}\text { Vertical flow measurements under } \\
\text { pumping conditions }\end{array}$} \\
\hline & & Length & Top & Bottom & & $\begin{array}{l}\text { Depth of } \\
\text { measurement } \\
\text { (ft bls) }\end{array}$ & $\begin{array}{c}\text { Flow } \\
(\mathrm{gal} / \mathrm{min})\end{array}$ & $\begin{array}{c}\text { Pumping } \\
\text { rate } \\
\text { (gal/min) }\end{array}$ & $\begin{array}{l}\text { Depth of } \\
\text { measurement } \\
\text { (ft bls) }\end{array}$ & $\begin{array}{c}\text { Flow } \\
\text { (gal/min) }\end{array}$ \\
\hline \multirow[t]{12}{*}{ RAP1-6R } & Bedrock & 20.2 & 51.5 & 71.7 & 72.0 & 44.0 & -0.008 & 0.25 & 39.9 & +0.228 \\
\hline & & & & & & 52.9 & -0.004 & & 42.9 & +0.218 \\
\hline & & & & & & 57.9 & -0.004 & & 51.9 & +0.228 \\
\hline & & & & & & 63.0 & 0 & & 52.9 & +0.228 \\
\hline & & & & & & 68.1 & 0 & & 55.4 & +0.218 \\
\hline & & & & & & & & & 57.9 & +0.208 \\
\hline & & & & & & & & & 60.4 & +0.208 \\
\hline & & & & & & & & & 63.0 & +0.192 \\
\hline & & & & & & & & & 65.9 & +0.171 \\
\hline & & & & & & & & & 66.9 & +0.083 \\
\hline & & & & & & & & & 68.1 & +0.035 \\
\hline & & & & & & & & & 70.7 & 0 \\
\hline
\end{tabular}

18 VOCs in Ground Water by Diffusion Samplers and a Low-Flow Method, and Borehole-Flowmeter Data, Hanscom AFB, Mass. 